\title{
ANALISIS FAKTOR: KONSEP, PROSEDUR UJI \\ DAN INTERPRETASI
}

Oleh : Purwanto*

\section{Abstrak}

Factor analysis is a test of construct validity. The test is taken by testing so much items or variables and extracting to be lesser and simpler factors. The extraction is carried by unifying some items or variables having significant common variance as they measure the same dimension. In its application, factor analysis can be exploratory or confirmatory. Exploratory factor analysis is used to understand some factors explaining a variabel that analysis does not work under a hyphotesis. On the other hand, confirmatory factor analysis hyphotezise some factors from some items or variables to guide its work. The analysis runs some steps : testing of analysis property, serving correlation matrix, doing extraction, making rotation, and labeling factors. The results of testing are interpreted in some ways. Data can be analyzed if assumptions are approved. Index of Kaiser Meyer Olkin must be over 0,80. Data must also be normal in Bartlet's test of sphericity. Items or variables make the same dimension or factor if they have intercolinnearity over 0,20. A factor can be developed if it has eigenvalues more than 1,00. An item support a factor if it has factor loadings more than 0,30. Then, the developed factors are labelled or named according to the characteristic of supporting items.

Kata kunci: Butir /variabel, ekstraksi, rotasi, faktor.

*) Purwanto, M.Pd. adalah Dosen Jurusan IImu Pendidikan (Tarbiyah) STAIN Surakarta 


\section{A. Pendahuluan}

Analisis faktor (AF) telah dikenal sangat luas di kalangan ilmuan sosial kuantitatif. Uji ini digunakan untuk memastikan apakah butirbutir tertentu mendukung faktornya dan faktor-faktor mendukung variabel. Uji ini juga dapat digunakan untuk mengetahui variabelvariabel bebas mana yang mendukung penjelasan atas variabel terikat tertentu. Uji ini menghasilkan sejumlah faktor yang dapat menjelaskan atau menjadi indikator mengenai suatu variabel. Faktor terjadi karena sifat struktural berada dalam satu hubungan (Ferguson dan Takane, $1989: 521$ ).

Dunia mempunyai kompleksitas yang sangat rumit yang sulit dijelaskan dan dipahami. Analisis faktor merupakan cara pengujian validitas konstruk yang sangat canggih, menawarkan usaha penyederhanaan kerumitan dengan meringkas kerumitan yang sangat banyak unsurnya ke dalam faktor yang lebih sederhana dan mudah dipahami. Cara ini membantu manusia menjelaskan kerumitan ke dalam ukuran yang lebih sederhana.

Kerumitan metode ini menjadikannya tidak terlalu dikenal luas dan digunakan dalam praktek penelitian. Namun pengembangan program-program komputer semacam SPSS dan Minitab mengatasi kesulitan dalam perhitungan yang panjang dan melelahkan. Walaupun begitu penggunaan AF masih menyisakan kesulitan dalam memberikan interpretasi hasil perhitungan. Untuk itu tulisan ini mendiskusikan tentang AF agar lebih banyak khalayak akrab dengan metode ini.

\section{B. Analisis Faktor dan Validitas Konstruk}

Dalam penelitian kuantitatif pengumpulan data dilakukan dengan melakukan pengukuran menggunakan instrumen alat ukur. Menurut Arikunto (1995: 3) pengukuran adalah kegiatan membandingkan sesuatu dengan alat ukurnya. Instrumen pengumpulan data adalah sebuah alat ukur yang digunakan untuk mengumpulkan data. 
Penelitian sosial kuantitatif dipengaruhi oleh cara penelitian yang dilakukan dalam ilmu alam. Pengaruh itu termasuk pula dalam cara pengumpulan data. Penggunaan alat ukur untuk pengumpulan data merupakan kegiatan yang dilakukan dalam ilmu alam yang mempengaruhi pengumpulan data dalam ilmu sosial.

Sebagaimana alat ukur dalam ilmu alam, maka alat ukur dalam ilmu sosial juga harus memenuhi syarat alat ukur dalam sistem pengukuran (metric systems). Syarat itu meliputi terpenuhinya validitas dan reliabilitas. Pertama, validitas. Instrumen alat ukur dikatakan valid apabila mengukur secara tepat keadaan yang ingin diukurnya. Misalnya : timbangan adalah alat ukur yang valid untuk mengukur keadaan berat, begitu pula alat ukur untuk keadaan alam lain seperti panjang, waktu, getaran bumi, suhu, dan sebagainya dan variabel dalam ilmu sosial seperti sikap, minat, penilaian, persepsi, kemampuan, dan sebagainya. Berbagai macam cara dapat digunakan untuk menguji validitas. Tergantung pada tujuan dilakukannya pengujian, maka uji validitas dapat berupa uji validitas isi, kriteria dan konstruk. Bila tujuan pengujian validitas adalah untuk mengetahui apakah butir instrumen mengukur isi variabel maka digunakan uji validitas isi. Bila tujuan pengujian validitas adalah untuk mengetahui apakah alat ukur mampu meramalkan berdasarkan kriteria eksternal tertentu maka dilakukan pengujian validitas kriteria. Bila tujuan pengujian validitas adalah untuk mengetahui apakah alat ukur sudah sesuai konstruksinya dengan konstruksi variabel maka pengujian yang dilakukan adalah menguji validitas konstruk. Kedua, realiabilitas. Reliabilitas berhubungan dengan kestabilan hasil pengukuran. Alat ukur harus memberikan hasil yang stabil pada hasil pengukurannya, karena mengukur hal yang sama menghasilkan ukuran yang berbeda-beda menyebabkan tidak dapat dipercayanya alat ukur tersebut. Pengujian relibilitas dapat dilakukan dengan berbagai metode di antaranya adalah metode tes ulang, paralel, belah dua, Alpha Cronbach, Rulon, Flanagan, Hoyt, KuderRichardson, dan sebagainya. 
Berbagai metode dikembangkan dalam pengujian validitas. Pertama, validitas isi diuji secara logis atau empiris. Secara logis, validitas isi diuji dengan mencermati kesesuaian butir yang ditulis dengan kisi-kisinya, baik dilakukan sendiri oleh pengembang instrumen maupun dimintakan pendapat kepada ahli (professional judgement). Secara empiris pengujian kesesuaian butir dengan kisikisi itu diuji dengan analisis korelasi butir-total untuk melihat sumbangan butir terhadap total variabel. Kedua, validitas kriteria dapat dibagi menjadi dua berdasarkan kriteria dasar untuk mengujinya, yaitu validitas konkuren dan prediktif. Bila kriteria telah ada pada saat pengujian validitas instrumen dilakukan, maka yang dilakukan adalah pengujian validitas konkuren. Sebaliknya, bila kriteria yang menjadi dasar menguji validitas belum ada pada saat pengujian karena masih harus diramalkan oleh hasil pengukuran menggunakan instrumen itu maka validitas diuji sebagai validitas prediktif. Ketiga, ketepatan konstruksi diuji dengan uji validitas konstruk. Pengujian dapat dilakukan dengan salah satu dari beberapa metode : konvergensi dan diskriminabilitas, matriks multitrait-multimethod (MTMM) dan analisis faktor (Kerlinger, 1996 : 736 - 750). Sebagai metode pengujian validitas konstruk, analisis faktor dibahas lebih lanjut dalam tulisan ini.

\section{Pengertian}

Analisis Faktor (AF) merupakan analisis untuk membuat kerumitan dunia menjadi ukuran yang lebih sederhana sehingga lebih mudah dijelaskan. AF adalah salah satu analisis multivariat yang dirancang untuk meneliti sifat hubungan antara variabel-variabel dalam satu perangkat tertentu yang pada dasarnya menunjukkan pola hubungan tertentu. Tujuan AF adalah menentukan apakah satu perangkat variabel dapat digambarkan berdasarkan berdasarkan jumlah "dimensi" atau "faktor" yang lebih sedikit daripada jumlah variabel (Hardjodipuro, $1988: 3$ ). Menurut Suryanto (1988: 234), AF adalah kajian tentang kesalingketergantungan antara variabelvariabel dengan tujuan untuk menemukan himpunan variabel baru 156 yang lebih sedikit jumlahnya dari variabel semula dan menunjukkan 
variabel-variabel mana dari variabel semula tersebut yang merupakan faktor persekutuan.

Menurut Kerlinger, AF merupakan keiritan upaya ilmiah yaitu mengurangi kelipatgandaan tes dan pengukuran sehingga jauh menjadi lebih sederhana dengan jalan memberitahukan hal-hal sebagai berikut : ada butir-butir tes atau ukuran yang saling dapat serasi atau sama tujuannya dan sejauh mana kesamaan itu, ukuranukuran apa saja yang mengukur hal yang sama dan seberapa jauhkah ukuran-ukuran tersebut mengukur hal atau karakteristik yang diukur. Di samping itu AF juga membantu menemukan dan mengidentifikasi keutuhan-keutuhan atau sifat-sifat mendasar yang melandasi tes dan pengukuran (Kerlinger, 1996 : 1000). Sebagai upaya penyederhaan kerumitan, Hardjodipuro (1988: 62) menyatakan bahwa AF merupakan penyederhaan ilmiah (scientific parsimony) karena analisis tersebut mengurangi kerumitan tes dan pengukuran menjadi suatu deskripsi ilmiah yang sederhana. AF membahas tes-tes atau pengukuran-pengukuran mana yang merupakan satu kelompok atau mana yang mengukur / menguji hal-hal yang sama tersebut. AF membantu mengurangi jumlah variabel yang digarap peneliti. AF juga membantu peneliti untuk menemukan dan mengidentifikasi satuan-satuan atau ciri-ciri yang mendasari suatu tes dan pengukuran.

\section{Penggunaan}

AF mempolakan begitu banyak butir tes ke dalam pola-pola yang lebih sederhana. Dimensi-dimensi yang diungkapkan oleh AF dapat diinterpretasikan sebagai ukuran-ukuran dari jumlah variasi yang tersusun secara berpola di mana taraf keteraturan atau saling ketergantungan dari variasi-variasi dapat dilihat dari jumlah dan kekuatan dimensi yang ditemukan. Salah satu tugas ilmu adalah menemukan susunan, pola dan keteraturan dalam suatu fenomena, sehingga AF dalam hal ini merupakan suatu alat ilmiah yang akurat (Hardjodipuro, 1988 : 12). 
Ditinjau dari penggunaannya, terdapat dua macam AF yaitu AF eksploratori (exploratory factor analysis) dan konfirmatori (confirmatory factor analysis). AF eksploratori adalah penggunaan AF untuk mengetahui faktor-faktor yang melandasi sehimpunan variabel atau sehimpunan ukuran. Sebaliknya AF konfirmatori adalah penggunaan AF untuk menguji hipotesis mengenai struktur faktor dalam sehimpunan data (Kerlinger, 1996 : 1032). AF eksploratori tidak menghipotesakan adanya sejumlah faktor dari butir-butir pengukur variabel. Butir-butir dibiarkan membentuk polanya sendiri dan menginformasikan ditemukan faktor-faktor. Sebaliknya, AF konfirmatori menghipotesakan telah ditemukannya sejumlah faktor dari variabel dan analisis dilakukan untuk menegaskan kemandirian faktor dan menguji kontribusi butir kepada faktor-faktornya. Sehubungan dengan itu Hardjodipuro (1988 : 53) berpendapat, dalam AF eksploratori peneliti berusaha merangkum data dengan cara mengelompokkan variabel yang saling berinterkorelasi yang mana variabel-variabel tersebut dipilih tanpa praduga adanya sruktur dasar potensial. Sebaliknya, AF konfirmatori dilakukan untuk menguji hipotesis-hipotesis mengenai struktur dasar faktor. Faktor-faktor tidak dicari tapi telah lebih dulu dihipotesakan (Crocker dan Algina, 1986 : 304). AF dilakukan untuk menguji eksistensi, kemandirian dan butir-butir yang menjadi muatannya (Kleinbaum dan Kupper, 1978 : 384). Dengan demikian tujuan AF adalah : (1) mengeksplorasi wilayah variabel guna mengetahui dan menunjukkan faktor-faktor yang diduga melandasi variabel tersebut, (2) menguji hipotesis tentang relasi antara variabel-variabel (Kerlinger, 1996 : 1035).

Kebanyakan AF bersifat eksploratif bila digunakan sebagai suatu alat untuk mengurangi jumlah variabel atau mengetahui pola-pola korelasi antara variabel tanpa tujuan untuk menguji teori. Dalam mengkonseptualisasikan kegunaan eksploratif atau reduktif, AF merupakan metode yang kuat dan sangat perlu untuk mengetahui kesahihan konstruk. AF merupakan metode untuk meringkas atau mengurangi sejumlah ukuran yang tidak begitu banyak yang disebut faktor-faktor dengan menyingkapkan faktor-faktor mana yang mengukur hal yang sama (Kerlinger, 1996 : 749). 


\section{E. Beberapa Konsep}

AF mengenal beberapa istilah teknis yang harus diketahui. Sebelum melakukan prosedur dan memberikan interpretasi hasil analisis maka perlu diketahui beberapa hal tentang : (1) variabel / butir, (2) faktor, (3) ekstraksi, (4) eigenvalues, (5) rotasi, (6) total common variance atau communalities, dan (7) factor loadings. Konsepkonsep itu dijelaskan sebagai berikut:

\section{Variabel / butir}

Butir adalah unit terkecil pengukur yang diperkirakan akan mengukur satu dimensi dari variabel. AF akan menguji apakah setiap butir itu memang mengukur masing-masing satu dimensi variabel atau beberapa butir sebenarnya mengukur dimensi yang sama. Variabel (bebas) adalah unit terkecil yang menjadi penjelas variabel terikat tertentu. Sebuah variabel terikat mungkin dijelaskan oleh sangat banyak variabel bebas, sehingga menjadi sulit dipahami variabel-variabel penjelasnya. AF membantu menyederhanakan dengan menyatukan beberapa variabel bebas yang ternyata mengukur hal yang sama ke dalam faktor, sehingga variabel terikat tidak dijelaskan oleh terlalu banyak variabel, tapi hanya beberapa variabel (faktor) saja.

\section{Faktor}

Faktor adalah beberapa butir / variabel yang sebenarnya mengukur dimensi yang sama. Mengukur / menjelaskan variabel menggunakan terlampau banyak butir / variabel menjadi sulit memahami dimensi yang dimiliki variabel. AF membantu membuat penyederhanaan dengan mengumpulkan beberapa butir / variabel yang mengukur dimensi sama menjadi satu faktor.

\section{Ekstraksi}

Menurut arti kamus, ekstraksi (extraction) berarti memeras dan ekstrak (extract) berarti sari (Echols dan Shadily, 1993 : 227). Beberapa butir / variabel kemungkinan mengukur / menjelaskan dimensi yang sama atau memiliki faktor yang sama. Prosedur 
ekstraksi dilakukan untuk memeras banyak butir / variabel hingga ditemukan beberapa faktor saja yang menjadi sarinya.

\section{Eigenvalues}

Eigenvalues adalah ukuran nilai tertentu dari varians butir agar dapat dikonstruksi menjadi sebuah faktor. Setiap butir memiliki eigenvalues 1,00 bila digunakan untuk mengukur variabel. Sebuah faktor dimaksudkan untuk meringkas butir-butir yang mempunyai dimensi sama. Pekerjaan meringkas berfungsi dengan baik bila faktor berperan lebih baik dibandingkan butirbutir berdiri sendiri, sehingga faktor harus mempunyai varians di atas 1,00. Oleh karena itu faktor hanya akan dipertahankan bila memiliki eigenvalues di atas 1,00.

\section{Rotasi}

Rotasi (rotation) mempunyai arti kamus perputaran (Echols dan Shadily, 1993 : 491). Dalam AF, rotasi dimaksudkan sebagai proses memutar sumbu mendekati koordinat butir / variabel, sehingga diketahui pengelompokkan dan sumbangan butir kepada faktor.

\section{Communalities}

Faktor terbentuk karena adanya varians bersama beberapa butir. Setiap butir mengandung varians umum, spesifik dan galat. Varians umum (common variance) merupakan bagian dari varians butir tersebut yang disumbangkan kepada setiap faktor. Total varians umum yang disumbangkan kepada semua faktor disebut komunalitas yang dinotasikan dengan $h^{2}$. Bila metode ekstraksi menggunakan principal component analysis, maka komunalitas akan selalu 1,00 (satu), karena metode ekstraksi ini tidak memisahkan varians umum, spesifik dan galat.

\section{Factor loadings.}

Muatan faktor (factor loadings) yang dinotasikan dengan $h$ merupakan sumbangan varians bersama sebuah butir kepada faktor. Sebuah butir menjadi muatan sebuah faktor bila 
memberikan sumbangan yang besar hanya pada satu faktor tersebut dan tidak pada faktor lainnya.

\section{F. Prosedur Uji}

Beberapa data diperlukan dalam AF. Data-data tersebut diperoleh dari AF dengan mengikuti prosedur uji. Prosedur uji melibatkan beberapa langkah. Menurut Norrusis (1988 : 1011 - 1022), langkahlangkah yang harus ditempuh dalam AF adalah menghitung korelasi matriks, melakukan ekstraksi, melakukan rotasi dan penamaan atau penafsiran faktor. Sebelum analisis dilakukan beberapa asumsi harus terpenuhi, sehingga secara keseluruhan langkah-langkah uji AF adalah: (1) menguji kelayakan analisis, (2) menyajikan matriks korelasi, (3) melakukan ekstraksi, (4) melakukan rotasi, dan (5) memberikan penamaan faktor. Langkah-langkah tersebut dijelaskan sebagai berikut:

\section{Menguji kelayakan analisis}

Menguji kelayakan analisis dilakukan untuk melihat terpenuhinya asumsi sebagai syarat dapat dilakukan AF. Kriteria untuk mengetahui apakah suatu data dapat dianalisis faktor ditentukan oleh dua hal yaitu harga koefisien Kaiser-Meyer-Olkin (KMO) sampling adequacy dan Bartlett's sphericity test. Uji KMO sampling adequacy diperlukan untuk melihat kecukupan sampel yang dianalisis dan uji Bartlett untuk melihat normalitas data yang akan dianalisis. Dengan terpenuhinya asumsi maka kesimpulan AF mempunyai kemampuan generalisasi (generalizability).

\section{Menyajikan matriks korelasi}

Matriks korelasi menyajikan interkorelasi antarbutir. Matriks diperlukan untuk mengetahui butir-butir yang saling berkorelasi tinggi dan rendah. Butir yang saling berkorelasi tinggi berarti mengukur dimensi yang sama dan sebaliknya.

\section{Melakukan ekstraksi}

Proses ekstraksi dilakukan untuk mendapatkan lebih sedikit 
faktor (eigenvalues factor) dari sejumlah banyak butir / variabel dan sumbangan faktor terhadap keseluruhan butir (total variance explained). Terdapat beberapa metode untuk melakukan ekstraksi. Menurut Paryono (1994 : 316 - 317), ekstraksi faktor dapat dilakukan menggunakan metode : (1) analisis komponen utama (principal component analysis), (2) pemfaktoran sumbu utama (principal axis factoring), (3) pemfaktoran kemiripan maksimal (maximum likelihood factoring), (4) pemfaktoran alpha (alpha factoring), (5) pemfaktoran citra (image factoring), (6) kuadrat terkecil tidak dibobot (unweighted least squares), dan (7) kuadrat terkecil tergeneralisir (generalized least squares).

\section{Melakukan rotasi}

Rotasi adalah proses memutar sumbu mendekati koordinat titiktitik butir / variabel. Proses ekstraksi hanya menentukan jumlah faktor yang meringkas keseluruhan butir, namun belum menentukan distribusi butir-butir ke dalam faktor-faktor yang meringkasnya. Rotasi melakukan proses yang belum dilakukan oleh prosedur ekstraksi dengan menarik butir-butir ke dalam faktor-faktor terdekat. Rotasi dapat dilakukan dengan satu dari beberapa metode : varimax, quartimax, equamax dan oblimin (Paryono, 1994 : 317). Rotasi dapat dilakukan dengan memutar membentuk sudut $90^{\circ}$ (ortogonal) atau tidak.

\section{Memberikan penamaan faktor.}

Langkah terakhir adalah menamai (labeling) faktor yang terbentuk dari proses ekstraksi dan rotasi. Nama diberikan berdasarkan kesamaan ciri butir yang menjadi muatan faktor.

\section{G. Interpretasi Hasil Uji}

Berdasarkan hasil uji AF, interpretasi harus dilakukan. Interpretasi mengacu kepada hasil analisis dari prosedur uji AF, yaitu : (1) KaiserMeyer-Olkin (KMO) sampling adequacy, (2) uji normalitas Bartlett (Bartlett's test of sphericity), (3) matriks korelasi, (4) eigenvalues, (5) communalities, (6) total variance explained, dan (7) factor 
loadings. Untuk memudahkan interpretasi, hasil uji itu dikelompokkan berdasarkan kepentingan interpretasi yaitu : (1) menguji kelayakan analisis, (2) menyajikan matriks korelasi, (3) melakukan ekstraksi, (4) melakukan rotasi dan (5) memberi nama faktor. Beberapa tabel hasil uji AF menggunakan program SPSS for Windows version 10.00 disajikan untuk menjadi bahan yang diinterpretasikan.

\section{Menguji kelayakan analisis.}

Untuk mengetahui kelayakan analisis berikut disajikan tabel hasil perhitungan KMO dan Bartlett menggunakan program SPSS :

KMO and Bartlett's Test

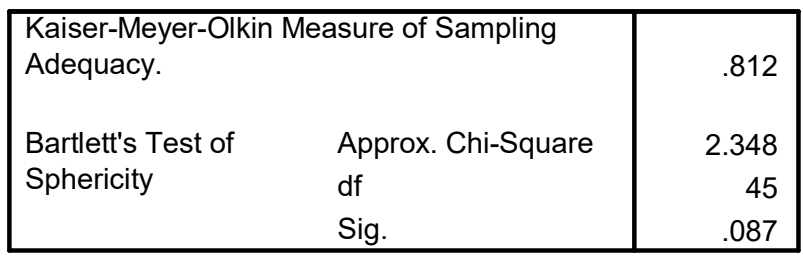

Dari tabel tersebut dapat disimpulkan bahwa :

a. Sampel mencukupi apabila butir / variabel direspons oleh responden sekurangnya 5 kali jumlah butir / variabel. Kecukupan sampling (sampling adequacy) akan terlihat dalam koefisien KMO. Syarat dilakukan analisis sudah terpenuhi karena sampel sudah cukup yang ditunjukkan oleh koefisien KMO sebesar 0,812. Bila mengggunakan kriteria yang ditetapkan oleh Guilford (1982 : 53) di mana KMO 0,80 sudah baik maka koefisien $\mathrm{KMO}$ sebesar 0,812 menunjukkan sampel telah mencukupi untuk dilakukan AF.

b. Uji Bartlett digunakan untuk menguji normalitas data. Data berdistribusi normal apabila $\chi^{2}{ }_{\text {hitung }}<\chi_{\text {tabel }}^{2}$ atau taraf signifikansi yang ditetapkan lebih kecil dari batas taraf signifikansi hasil perhitungan. Bila ditetapkan taraf signifikansi sebesar $1 \%$ atau paling tinggi $5 \%$ sebagaimana digunakan dalam banyak pengambilan keputusan dalam 
ilmu sosial maka data yang akan dianalisis telah berdistribusi normal. Hal itu ditunjukkan oleh approximate chi-square sebesar 2,219 yang hanya akan tidak normal bila taraf signifikansi yang ditetapkan paling kurang 8,7\%. Dengan terpenuhinya normalitas data maka AF dapat digunakan untuk analisis data tersebut.

\section{Menyajikan matriks korelasi}

Matriks korelasi disajikan untuk melihat pengelompokkan butirbutir dalam kluster-kluster. Secara teoritik, butir dalam satu kluster akan berkorelasi tinggi (minimal 0,20) dan butir-butir di luar kluster berkorelasi rendah (di bawah 0,20). Kluster-kluster itulah yang akan menjadi faktor dalam proses ekstraksi. Untuk menafsirkan matriks korelasi maka disajikan tabel matriks korelasi. Tabel ini telah dimodifikasi dari hasil print out dengan menghilangkan koefisien di bawah 0,20 dan korelasi butir dengan dirinya sendiri sebesar 1,00.

\section{Correlation Matrix}

\begin{tabular}{|l|l|l|l|l|l|l|l|l|l|l|}
\hline Correl & B1 & B2 & B3 & B4 & B5 & B6 & B7 & B8 & B9 & B10 \\
\hline B1 & & & & & & & & & & \\
\hline B2 & 0,686 & & & & & & & & & \\
\hline B3 & & & & & & & & & & \\
\hline B4 & & & & & & & & & & \\
\hline B5 & & & & & & & & & & \\
\hline B6 & & & 0,413 & & & & & & & \\
\hline B7 & & & & 0,329 & & & & & & \\
\hline B8 & & & & & 0,326 & & & & & \\
\hline B9 & & & & & & & & & & \\
\hline B10 & & & & & & & & & 0,892 & \\
\hline
\end{tabular}

Dari tabel matriks korelasi tersebut maka dapat diketahui pengelompokkan butir dalam kluster sebagai berikut : 


\begin{tabular}{|l|l|l|}
\multicolumn{1}{c}{ Kluster } & \multicolumn{1}{c}{ Butir } & Koefisien korelasi \\
\hline 1 & 1,2 & 0,686 \\
\hline 2 & 3,6 & 0,413 \\
3 & 4,7 & 0,324 \\
4 & 5,8 & 0,326 \\
5 & $\$, 10$ & 0,892 \\
\hline
\end{tabular}

\section{Melakukan ekstraksi}

Data hasil proses ekstraksi menggunakan program SPSS disajikan kembali dalam tabel sebagai berikut :

Total Variance Explained

\begin{tabular}{|c|c|c|c|c|c|c|}
\hline \multirow{2}{*}{$\begin{array}{c}\text { Compo- } \\
\text { nent }\end{array}$} & \multicolumn{6}{|c|}{ Initial Eigenvalues Extraction sum of squared loadings } \\
\cline { 2 - 7 } & Total & \% of var & Cumm \% & Total & \% of var & Cumm \% \\
\hline 1 & 2.623 & 26.229 & 26.229 & 2.623 & 26.229 & 26.229 \\
2 & 1.998 & 19.976 & 46.205 & 1.998 & 19.976 & 46.205 \\
3 & 1.549 & 15.483 & 61.693 & 1.549 & 15.483 & 61.693 \\
4 & 1.136 & 11.363 & 73.056 & 1.136 & 11.363 & 73.056 \\
5 & 1.009 & 10.094 & 83.151 & 1.009 & 10.094 & 83.151 \\
6 & .931 & 9.310 & 92.461 & & & \\
7 & .559 & 5.588 & 98.049 & & & \\
8 & .195 & 1.949 & 99.998 & & & \\
9 & $\mathbf{1 . 7 3 2 E - 4}$ & $\mathbf{1 . 7 3 2 E - 3}$ & 100.00 & & & \\
10 & $\mathbf{- 5 . 3 2 E - 1 6}$ & $\mathbf{- 5 . 3 E - 1 5}$ & 100.00 & & & \\
\hline
\end{tabular}

Dari data tabel tersebut dapat diinterpretasikan sebagai berikut

a. Butir disusun berdasarkan urutan besarnya sumbangan terhadap keseluruhan kualitas butir. Butir 1 memberikan sumbangan sebesar $26,23 \%$ dari keseluruhan butir, butir 2 menyumbangkan $19,98 \%$, butir 3 sebesar $15,488 \%$ dan 
seterusnya.

b. Dari 10 butir yang dicobakan sesungguhnya dapat diringkas menjadi lima faktor karena beberapa butir mengukur dimensi yang sama. Faktor yang dipertahankan adalah yang memiliki eigenvalues di atas 1,00 (Marascuilo dan Levin, 1983 : 237).

c. Kelima faktor memberikan sumbangan total sebesar $83,151 \%$ dari keseluruhan kualitas instrumen.

\section{Melakukan rotasi}

Rotasi akan mengarahkan untuk melihat lebih jelas pengelompokkan dan besarnya sumbangan butir ke dalam faktor. Butir akan menjadi bagian dari faktor apabila memberikan sumbangan (factor loadings) paling tidak 0,30 (Kerlinger, 1996 : 1018). Total varians bersama (communalities) adalah 1,00 pada semua butir karena metode yang digunakan untuk proses ekstraksi adalah analisis komponen utama (principal component analysis) yang tidak memisahkan varians umum, spesifik dan galat. Hasil proses rotasi ortogonal dengan metode varimax

Rotated Component Matrix

\begin{tabular}{|l|r|r|r|r|r|}
\hline & \multicolumn{5}{|c|}{ Component } \\
\cline { 2 - 6 } & \multicolumn{1}{|c|}{1} & \multicolumn{1}{|c|}{2} & \multicolumn{1}{c|}{3} & \multicolumn{1}{c|}{4} \\
\hline B1 & .576 & $-6.07 \mathrm{E}-02$ & $-3.03 \mathrm{E}-02$ & -.118 & $4.243 \mathrm{E}-02$ \\
B2 & .976 & $-6.13 \mathrm{E}-02$ & $-2.97 \mathrm{E}-02$ & -.118 & $4.400 \mathrm{E}-02$ \\
B3 & $-2.83 \mathrm{E}-02$ & $-4.19 \mathrm{E}-02$ & .924 & $-6.03 \mathrm{E}-03$ & $-1.92 \mathrm{E}-02$ \\
B4 & .116 & $-3.58 \mathrm{E}-02$ & $3.055 \mathrm{E}-02$ & $3.200 \mathrm{E}-02$ & .919 \\
B5 & $-5.13 \mathrm{E}-02$ & $1.413 \mathrm{E}-03$ & $-2.21 \mathrm{E}-03$ & .787 & -.394 \\
B6 & -.101 & $1.434 \mathrm{E}-02$ & .917 & $-1.48 \mathrm{E}-02$ & $1.378 \mathrm{E}-02$ \\
B7 & .280 & $5.243 \mathrm{E}-02$ & $-3.55 \mathrm{E}-02$ & .271 & .314 \\
B8 & -.224 & $-1.72 \mathrm{E}-02$ & $2.077 \mathrm{E}-02$ & .775 & .114 \\
B9 & $-3.55 \mathrm{E}-02$ & .995 & $3.047 \mathrm{E}-02$ & $-2.77 \mathrm{E}-02$ & $-4.77 \mathrm{E}-02$ \\
B10 & $-3.84 \mathrm{E}-02$ & .697 & $3.052 \mathrm{E}-02$ & $5.073 \mathrm{E}-02$ & $6.584 \mathrm{E}-03$ \\
\hline
\end{tabular}

Extraction Method: Principal Component Analysis.

Rotation Method: Varimax with Kaiser Normalization.

a. Rotation converged in 5 iterations. 
(variance maximum) memberikan hasil sebagai berikut:

Dari penyajian tabel hasil rotasi tersebut dapat dilihat pengelompokkan butir ke dalam faktor dan besar sumbangannya sebagai berikut:

\begin{tabular}{|c|c|c|}
\hline Faktor & Butir & Muatan faktor \\
\hline 1 & 1 & 0,576 \\
& 2 & 0,976 \\
2 & 9 & 0,995 \\
& 10 & 0,687 \\
3 & 3 & 0,924 \\
& 6 & 0,917 \\
4 & 5 & 0,787 \\
& 8 & 0,775 \\
5 & 4 & 0,919 \\
& 7 & 0,314 \\
\hline
\end{tabular}

\section{Memberi nama faktor}

Hasil rotasi menunjukkan pengelompokkan dan besar sumbangan butir ke dalam faktor. Faktor-faktor masih berupa angka 1 sampai 5 yang belum memiliki nama. Selanjutnya, masing-masing faktor diberi nama sesuai dengan kesamaan ciri yang dimiliki oleh butir-butir yang mendukungnya. Berikut contoh pemberian nama dari kesamaan ciri butir-butir yang menjadi muatannya :

\begin{tabular}{|c|l|l|}
\hline Faktor & Butir & Nama / Label \\
\hline 1 & 1,2 & Unit \\
2 & 9,10 & Kelas \\
3 & 3,6 & Hubungan \\
4 & 5,8 & Sistem \\
5 & 4,7 & Transformasi \\
\hline
\end{tabular}




\section{H. Kesimpulan}

AF merupakan analisis uji validitas konstruk. Analisis dilakukan dengan menguji butir-butir atau variabel-variabel yang sangat banyak diringkas menjadi faktor-faktor yang lebih sedikit dan sederhana. Peringkasan dilakukan dengan menyatukan butir-butir atau variabelvariabel yang mempunyai varians faktor bersama yang besar ke dalam satu faktor karena dalam keadaan demikian butir-butir atau butir-butir tersebut sebenarnya mengukur dimensi yang sama. Dalam penggunaannya AF dapat dilakukan secara eksploratif maupun konfirmatif.

AF ditempuh dengan prosedur yang melibatkan beberapa langkah yaitu: menguji kelayakan analisis, menyajikan matriks korelasi, melakukan ekstraksi, melakukan rotasi dan memberi nama faktor. Hasil perhitungan dari langkah-langkah uji akan ditafsirkan. Data dapat dianalisis bila sampel cukup dan berdistribusi normal. Hal itu ditunjukkan oleh koefisien KMO minimal 0,80 dan taraf signifikansi yang ditetapkan di bawah rekomendasi hasil perhitungan. Butir yang mempunyai dimensi sama memiliki interkorelasi minimal 0,20 dalam matriks korelasi. Faktor hasil ekstraksi akan dipertahankan bila memiliki eigenvalues minimal 1,00. Sebuah butir memberi dukungan pada sebuah faktor bila mempunyai muatan faktor minimal 0,30. Faktor hasil proses rotasi selanjutnya diberi nama atau label sesuai dengan sifat butir-butir muatannya.

\section{DAFTAR PUSTAKA}

Daftar Pustaka

Arikunto, Suharsimi (1995) Dasar-dasar Evaluasi Pendidikan. Jakarta : Bumi Aksara

Crocker, Linda dan Algina, James (1986). Introduction to Classical and Modern Test Theory. Forth Worth : Holt, Rinehart and Winston, Inc. Echols, John M dan Shadily, Hassan (1993). Kamus Inggris Indonesia. Jakarta : PT Gramedia

Fergusson, George A dan Takane, Yoshio (1989). Statistical Analysis in Psychology and Education. New York : McGraw Hill Book Company 
Guilford, J.P. (1982). Psychometric Methods. New Delhi : Tata McGraw Hill Publishing Co.

Hardjodipuro, Siswojo (1988). Aplikasi Komputer dan Analisis Multivariat: Analisis Faktor. Jakarta: P2LPTK Ditjen Dikti Depdikbud Kerlinger, Fred N. (1996). Asas-asas Penelitian Behavioral. Terjemahan Landung R Simatupang. Yogyakarta : Gadjah Mada University Press Kleinbaum, David G dan Kupper, Lawrence L (1978). Applied Regression Analysis and Other Multivariable Methods. Belmont, California : Wadworth Publishing Company Inc.

Marascuilo, Leonard A dan Levin, Joel R (1983). Multivariate Statistics in the Social Sciences : A Researcher's Guide. Monterey, California

: Books / Cole Publishing Company

Norrusis, Marijan J (1988). SPSS/PC+ v. 3.0 Advanced Statistics Update Manual. Chicago : SPSS Inc.

Paryono, Petrus (1994). Mengolah Data dengan SPSS / PC+. Yogyakarta : Andi Offsett

Suryanto (1988). Metode Statistika Multivariat. Jakarta : P2LPTK Ditjen Dikti Depdikbud 